\title{
Mongolian place names in Fernão Mendes Pinto's Peregrinação
}

\section{AFONSO XAVIER CANOSA*1 and BENJAMIN BROSIG ${ }^{2}$}

\author{
${ }^{1}$ Facultade de Filoloxía e Tradución; Tradución e Paratradución (TI4), Universidade de Vigo, Campus Universi- \\ tário Lagoas-Marcosende, C.P. 36310 Vigo (Galiza) \\ ${ }^{2}$ Institute of Linguistics, Academia Sinica, 128, Section 2, Academia Road 115, Taipei, Taiwan, R.O.C. \\ E-mail: benjamin.brosig@gmx.de
}

Received: December 12, 2019 • Accepted: August 11, 2020

(c) 2021 The Authors

\section{ABSTRACT}

The Mongolic term khaan ('king'), for which there is full correspondence, semantic and phonological, in sixteenth century Portuguese cão, is used as a starting-point to identify the graphemes that correspond to several Mongolic consonants in place names transcribed in the chapters related to the Tartars in Fernão Mendes Pinto's Peregrinação (1614). With the deduced rules of pronunciation at hand, it is possible to establish new pairs of lexical correspondences and solve a brief lexicon extracted from the list of Tartar toponyms.

\section{KEYWORDS}

Fernão Mendes Pinto, Classical Mongol, Portuguese, historical geography, Mongolian place names, Asian toponymy, Peregrinação

\footnotetext{
*Corresponding author. E-mail: canosarodrigues@gmail.org
} 


\section{INTRODUCTION}

Peregrinação (Pilgrimage) is the title given in Portuguese (original first edition, 1614; translated into English in 1653) to a long report, written as memories in the last period of his life, by Fernão Mendes Pinto (c. 1510-1583), a Portuguese sailor, diplomat and merchant who spent 21 years of his life in Asia. Before his return to Lisbon, Pinto had already written a description of the easternmost areas of Asia as part of a widely spread collection of letters sent from Asia and published in Europe in 1554 (Mello 1989). He has also been recently considered the most probable author of another report on China that remained anonymous (Barreto 2010).

The value of Pinto's work as a first-hand description of the history and geography of Asia was soon noticed by specialists both in Portugal and abroad (Lopes 2010; Canosa 2013). This is the case for Purchas who used Pinto as a main source to describe the Tartars in his world geography collection (Purchas 1625, vol. 3: 251-281) well before the first complete translation of Peregrinação into English by Henry Cogan (Pinto, 1653). Indeed, despite the fact that new and more accurate reports on the coastal and nearby areas of Asia kept on arriving in Europe as the Europeans were undertaking further expeditions, knowledge on the geography of more distant and less commercially relevant areas such as Tartaria was still scarce at the time when Peregrinação was published. ${ }^{1}$

The section most relevant for Tartaria corresponds to the chapters 117 to 131 of the Peregrinação (Pinto 1614; 1653: chs. 38-41) ${ }^{2}$ in which Pinto describes the episodes that occurred in northern China and in the lands of the Tartars with whom he lived together with a group of Portuguese until, as a reward for the services provided, they were taken to a safe way to the sea. In his report, Pinto records place names and even whole sentences of the language used in court and in religious invocations, most of the time providing a translation into Portuguese. However, the very presence of these transcriptions in the original Asian language, not deciphered until now, ${ }^{3}$ is one of the main difficulties when assessing the descriptive value of this section.

In order to contribute to a better understanding of Pinto's descriptions, all sentences with place names were extracted from the chapters referring to the Tartars as transcribed in the first editions in Portuguese (1614) and English (1653). From this, those toponyms were selected that can with some confidence be related to Mongolian words, so as to investigate their meaning and phonetic value.

\footnotetext{
${ }^{1}$ This initial value as a source of geographical knowledge lost importance as the work became popular (with nineteen editions in Europe in the 17th century), and the readers began to approach Pinto for entertainment rather than for his historical value (Collis 1949: 195-302). The apologetic prologue of the first English edition (Pinto 1653) is a good example of the need that the translator felt to explain that what seemed too exotic to be credible for the average European reader was actually based on facts.

2 For specific analyses on these chapters see Charignon \& Ménard (1935: 265-359), Collis (1949: 139-142) and Alves (2010: vol. 3, 148-167).

${ }^{3}$ Charignon \& Ménard (1935: 280-288) do read several terms discussed in this paper as Chinese, but the sound correspondences that their readings implicate are hard to defend. For instance, they relate Tuymicão to 'T'ai-tsingkang 太青岡' which they explain as mountain(s) of a region named T'ai-tsing (1935: 288). As will become clear below, only the sound correspondences for the third syllable are sound. Among later researchers, Aubin (2010: 158. n. 2) simply declares that Tuymicão cannot be identified as either Chinese nor Mongol, without refering to Charignon \& Ménard in her notes to the chapters on the Tartars in Peregrinação. Collis (1949: 140) acknowledges the existence of these etymologies, but declares that 'they fail to convince', while Jin, although mentioning Charignon \& Ménard's work (2010a: 106. n. 5; 2010b), does not consider it as relevant for assessing Mendes Pinto's knowledge of the Chinese language (2010b).
} 
This paper, then, is structured as follows. In Section 2, we will provide some general background on the Mongolic languages and on the phonemes most relevant for the terms under investigation. In Section 3, we will study concordances of lexical units that have the meaning 'king', explaining the different spellings of the name in terms of different degrees of semantic transparency. In Section 4, we identify the Mongolian term for 'Great Wall of China', a concept which is readily accessible at present time, but was not so for Pinto's readers in the $16^{\text {th }}$ century. Section 5 provides a discussion on several problematic cases of phoneme correspondence between $16^{\text {th }}$ century Mongolian and Portuguese, thus accounting for the choice of graphemes by Pinto and his editors. In Section 6, these rules of phonetic correspondence are applied to create a list of Mongolian terms that can be extracted from place names. Section 7 concludes the paper. ${ }^{4}$

\section{THE MONGOLIC LANGUAGES AND THE PORTUGUESE TRANSCRIPTIONS}

The term Mongolic or Mongol represents a group of languages and dialects spoken mainly in present-day Mongolia and neighbouring areas in Russia and China, but also in territories west of the Caspian sea and in Afghanistan (Janhunen 2003a: xvi) as remnants of the geographic dispersion that took place 800 years ago in the times of the Mongol Empire (Janhunen 2003b: 1). The proximity of these languages makes it difficult to define a taxonomy, and the number of varieties will vary according to the criteria used (Janhunen 2003a: xvii). Common Mongolic (Janhunen 2012a: 4-6) or Central Mongolic (Brosig \& Skribnik 2018: 555) comprises those varieties that stayed in contact at least well into the $17^{\text {th }}$ century. These include Khalkha Mongolian, the de-facto official dialect of the Mongolian state, and varieties such as Chakhar and Khorchin in the Chinese province Inner Mongolia, along with Buryat in and around the Russian republic Buryatia and Oirat in the west of the Mongolian state, in Kalmykia and in several north-western parts of China such as Alasha (Inner Mongolia), Qinghai, and Xinjiang. Khalkha and the non-Oirat/non-Buryat varieties of Inner Mongolia arguably form a sub-branch that is conventionally called Mongolian (Svantesson et al. 2005: 141-144, 148), a convention that we shall follow in the remainder of this paper.

Diachronically, these contemporary Mongolic languages developed from Middle Mongol, the language of Genghis Khan's immediate descendants attested in texts from the $13^{\text {th }}$ to early $15^{\text {th }}$ century mainly in Mongol, Chinese, Phagspa and Arabic script (Rybatzki 2003: 57-58). After 150 years from which very few documents survive, sources written in Mongol script resurface in the late $16^{\text {th }}$ century which to some extent begin to reflect modern dialectal grammar, but are very substantially influenced by a standardized written language of religion, the so-called Classical Mongol of the $17^{\text {th }}$ to $19^{\text {th }}$ century which cultivated a supra-dialectal standard (Poppe 1954: $2-4)$. Moreover, the conservative orthography of this time by and large preserves the phonological features of Middle Mongol (Janhunen 2012a: 6). Partial phonological analysis for dialects during this early modern period are in principle possible on the basis of evidence of preceding and subsequent varieties in combination with inferences from orthographic peculiarities and

${ }^{4}$ In terms of division of work, Canosa bears the main responsibility for the overall line of argument and the Portuguese data, while Brosig bears the main responsibility for the Mongolic data. We want to express our gratitude to Hans Nugteren for helpful comments on an earlier version of this paper and to Christopher Atwood and M. Bayarsaikhan for some input on the term Singrachirau. For the Portuguese side, we want to thank Stephen Parkinson, Henrique Monteagudo and José Antonio Souto Cabo for helpful suggestions on the various readings of $<\mathrm{ch}>$ and $<\mathrm{au}>$. 
inconsistencies. However, the existing research mostly focuses on the philological or grammatical analysis of individual (major) text sources as consistent grammatical systems rather than on what a corpus of several unrelated regional sources could tell about their underlying dialects.

The language spoken in the period in which Fernão Mendes Pinto lived in Asia corresponds to the undocumented transitional period between Middle Mongol and the re-emergence of sources written by speakers of early modern Central Mongolic varieties. Consequently, while the best readily available comparative data has to be taken from Middle Mongol and modern Central Mongolic dialects, it is necessary to keep in mind that the lexemes noted down by Pinto reflect an intermediate stage. Another problem is the identification of the particular language varietie(s) of the place names from those within the Mongolic language family. In Peregrinação (1614), Pinto starts his route near what is now Beijing, crosses the Great Wall and travels to areas that would lie east and south of the contemporary Mongolian state. Consequently, it is dialects such as Khorchin, Kharchin and Eastern Tümet in eastern Inner Mongolia and Baarin, Chakhar and Western Tümet in central Inner Mongolia that can be taken as starting points for comparison.

The following are some phonetic characteristics of Mongolian that should be mentioned for the purposes of this article:

- Modern Central Mongolic varieties distinguish between short and long vowels (Janhunen 2012a: 26) which correspond to disyllabic double vowel sequences in [Late] Middle Mongol (Nugteren 2011: 58).

- Middle Mongol distinguished between nasal labial $/ \mathrm{m} /$, dental $/ \mathrm{n} /$ and, in rare cases, velar /n/ in word-final position (Nugteren 2011: 75, 243). In most dialects of Inner Mongolia, this state of affairs is retained: the loss of short word-final vowels after $/ \mathrm{n} /$ yielded word-final $/ \mathrm{n} /$, while Chinese loans ending in $/ \mathrm{y} /$ retained $/ \mathrm{y} /$. In a few dialects such as Khalkha [and Sönit], however, original word-final /n/ became $/ \mathrm{n} /$ (still contrasting to $\eta g$ with epenthetic [g] in several non-nominative case forms of old Chinese loans), while loss of short word-final vowels after $/ \mathrm{n} / \mathrm{created}$ a new class of words ending in /n/ (Janhunen 2012b: 162). ${ }^{5}$

- Middle Mongol had a phoneme $/ \mathrm{k}^{\mathrm{h}} /$ (with a positional allophone $\left[\mathrm{q}^{\mathrm{h}}\right]$ ) which is retained in Oirat, but becomes $/ \mathrm{x} /$ (with a positional allophone $[\chi]$ ) in Mongolian.

\section{LOOKING FOR A KEY TO DECIPHER THE CODE}

Pinto learnt from the Tartars both the place names and the sentences that he transcribes. Therefore, he had to look for suitable letters to represent sounds from a phonemic system quite different to the one of the language that he used for writing down his memories, Portuguese. The problem is even greater if we consider that, at that time, Portuguese was still in the process of standardization. So Pinto's writing may show diachronic, dialectal and idiolectal practices that differ from today's standard.

To handle these difficulties, we start with a term for which Pinto offers sufficient context to infer its meaning and sometimes even provided a direct translation: a compound name that in-

5 For instance, /n/ in Proto-Mongolic *ken 'who' was retained in Kharchin $x e n$, but changed to $x ə y$ in Sönit, while Proto-Mongolic ${ }^{\star}$ kulugana 'mouse' turned xulgan in both Kharchin and Sönit (see Nugteren 2011: 410, 432 for the

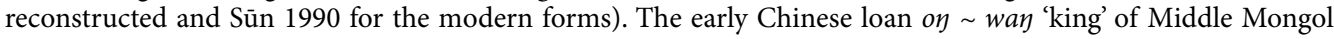
(cf. Rybatzki 2006: 122-124) is retained as way in both, but takes the genitive way [g]-i:y (as compared to xen-i: and $\left.x \mho l_{G} a n-i: y\right)$ in Khalkha. 
cludes the word for 'king. This word, written as qaGan in Mongol script, ${ }^{6}$ was qa'an in Late Middle Mongol (Sino-Mongol [Nugteren 2011: 395]) and takes the forms /xa:n/ (Baarin/Kharchin [Sūn 1990]) or /xa:y/ (Sönit [Sūn 1990]) in modern Inner Mongolian dialects, but it is written as cau or cão in the original Portuguese Peregrinação (1614) and as can or cam in the first English translation (1653).

\subsection{The term khaan as part of a word with meaning inferable from context}

\section{Table 1. Concordances of the form cão}

\begin{tabular}{|l|l|}
\hline \multicolumn{1}{|c|}{1614} & \multicolumn{1}{|c|}{1653} \\
\hline $\begin{array}{l}\text { E despois de a ter toda recolhida, se passou para ou- } \\
\text { tra cidade muyto mayor \& muyto mais nobre, que } \\
\text { se chamaua Tuymicão }\end{array}$ & $\begin{array}{l}\text { then having all his Army together, he went on to } \\
\text { another City far greater and fairer, called Tuymicoa }\end{array}$ \\
\hline $\begin{array}{l}\text { Passados algũs dias despois de ser chegado este Rey } \\
\text { a esta cidade de Taymicão, nos quais ouue algũas } \\
\text { festas notaueis, por se concluyr o casamento desta } \\
\text { princesa Meyca vidau irmam del Rey com este Em- } \\
\text { perador Caraõ de que tenho tratado }\end{array}$ & $\begin{array}{l}\text { After some time had been spent in the Celebrations } \\
\text { of certain remarkable Feasts, that were made for joy } \\
\text { of the conclusion of a marriage betwixt the Princess } \\
\text { Meica vidau, the Kings sister, and the Emperour of } \\
\text { Caran, the Tartar by the advice of his Captains resol- } \\
\text { ved to return anew to the Siege of Pequin }\end{array}$ \\
\hline $\begin{array}{l}\text { Partidos nós a noue dias do més de Mayo do anno de } \\
\text { 1544, desta cidade de Tuymicão, fomos aquelle dia } \\
\text { ja quasi noite dormir a hũs estudos que se chamauão } \\
\text { Guatipamor, em hum pagode por nome Naypatim, } \\
\text { nos quais os embaixadores ambos foraõ bem agasa- } \\
\text { lhados pelo Tuyxiuau da casa, que era o Reytor delles }\end{array}$ & $\begin{array}{l}\text { Being departed from this City of Tuymican on the } \\
\text { ninth day of May, in the year one thousand, five } \\
\text { hundred, forty and four, we came to lodg that night at } \\
\text { two Ambassadors were very well entertained by the } \\
\text { Tuyxivau of the house, which is as the Rector thereof }\end{array}$ \\
\hline $\begin{array}{l}\text { Apos isto lhe tornamos a preguntar pelo nome da- } \\
\text { quelle monstro, \& nos disse que era, Pachinarau du- }\end{array}$ \\
$\begin{array}{l}\text { beculem pinanfaquè, o qual auia setenta \& quatro } \\
\text { mil annos que nacera de hũa tartaruga por nome } \\
\text { Miganja, \& de hũ cauallo marinho de cento \& trin- } \\
\text { ta braças de comprido, que se chatonua Tibremvu- } \\
\text { cão, que fora Rey dos Gigaos de Fanjùs. }\end{array}$ & $\begin{array}{l}\text { After this we enquired of him how this Monster was } \\
\text { called, and he told us that his name was, Pachinavau } \\
\text { du beculem Prinaufaque, and that it was threescore } \\
\text { and fourteen thousand years since he was begotten } \\
\text { on a Tortois, called Migama, by a Sea-horse, that was } \\
\text { an hundred and thirty fathom long, named Tybrem } \\
\text { vucam, who had been King of the Giants of Fanius; }\end{array}$ \\
\hline
\end{tabular}

6 The transcription used for the Mongol script used in this paper is based on Poppe (1954: 17) which is probably the most widespread and simple transcription system available. We write $\langle j\rangle$ instead of $\langle\bar{j}\rangle$ for $r$ since no letter $<j>$ is employed by Poppe in the first place and $\langle\mathrm{G}\rangle$ instead of $\langle\gamma\rangle$ for ? so as to avoid its possible confusion with $<y>$. There are of course more precise transcription systems (including Balk \& Janhunen 1999), which are preferable when representing problematic spellings in particular primary sources. But to understand a transliteration, one needs to understand the relationship between graphs, graphemes and phonemes in its script, which might not be the case for all readers. Since the advantages of a strict transliteration of Written Mongol would not come to bear in this paper, we prefer the more straightforward correspondence between graphemes and phone(me)s that a transcription affords us. 


\begin{tabular}{|c|c|}
\hline 1614 & 1653 \\
\hline $\begin{array}{l}\text { Sendo el Rey auisado pelo seu embaixador como } \\
\text { trazia comsigo estoutro del Rey da Tartaria, o mã- } \\
\text { dou logo ao outro dia buscar a esta villa de Agimpur } \\
\text { onde estaua alojado, por hum seu cunhado irmão } \\
\text { da Raynha sua molher, principe muyto valeroso \& } \\
\text { de muyta rẽda que se chamaua Passilau Vacão }\end{array}$ & $\begin{array}{l}\text { He King being advertised by his Ambassadour, that } \\
\text { he brought another along with him from the King of } \\
\text { Tartaria, sent for him not long after from Agimpur } \\
\text { by the Brother of the Queen his wife, a very valiant } \\
\text { and rich Prince }\end{array}$ \\
\hline
\end{tabular}

Table 1 shows concordances with the term cão retrieved from a parallel corpus (Canosa 2018) comprising the chapters related to the Tartars according to the first Portuguese edition (Pinto 1614) and its English translation (Pinto 1653). Although Pinto's original language was Portuguese, the English translation is offered here not only for the purpose of translation, but also because it shows how certain spellings were understood in another language that uses Latin script in the $17^{\text {th }}$ century.

There are two occurrences, n. 2 and n. 5 (Table 1) where the proper name has been left out in English. For the remaining three, the ryhme - $\tilde{o}$ is transliterated in a non-uniform way, but tends to be rewritten as a vowel plus nasal consonant in English. That this correspondence is systematic is corroborated by other Asian place names mentioned in chapters other than the ones related to the Tartars. For instance, well-known place names such as Arracan and Siam in the English translation (Pinto 1653: 165) correspond to forms like Arracão and Sião in the first Portuguese edition (Pinto 1614: fol. 153v).

The English transliteration is coherent with the diachrony of Portuguese, since the diphthong $/ \tilde{\mathfrak{e}} \tilde{\mathrm{w}} /$, nowadays spelled as either - $\tilde{o} o$ or -am, represents the convergence of several Latin endings (Lipsky 1973; Parkinson 2002) (e.g. Latin -ANT, -ANEM > Portuguese -am; -ANUM > - $\tilde{o}$; -ŌNEM, UNT > -om) that were still in the process of standardization at the time of Pinto's writing (Oliveira 1536: cap. 45; Barros 1540: fol. 14r; Leão 1576: 27v-30v). The term khan itself illustrates this vacillation. Very early in the beginning of the $16^{\text {th }}$ century it was written as -am in such influential texts as the Portuguese edition of Marco Polo's travels (1502): Grã Cham, (fol. 2v) gram Cham (fol. 3r) 'Great Khan'. Closer to the period when Peregrinação was edited, the historian Diogo do Couto describes the pronunciation of the initial consonant as aspirate and distinguishes two possible spellings for the same word as Can and Cão (Couto 1612: fol. 212r). Consequently, only the ending -an (but not the initial consonant) would have been familiar enough to Portuguese speakers. ${ }^{7}$ As for its semantic value, João de Barros, a historian and geographer who met and consulted Pinto (Canosa 2013), described the term as equivalent to 'duke' among the Tartars and noted that it was used like a surname, attached to a preceding word that functions as a proper name (Barros 1615: 236-238).

The examples that explain the pronunciation and meaning of cão given by Couto (1612: fol. 212r) and Barros (1615: 236-238) show the same pattern that is also instantiated by cão in Table 1. They might therefore not be completely opaque, but could arguably be rewritten as phrases of the type:

7 'E como a pronuncião com que eles nomeam [can] não cabe na nossa [língua], e com uma aspiração que não se lhe entende mais que aquela, an, vierão a lhe chamar Can, e ainda se corrompeu mais, por que vulgarmente lhe chamam Cão' ['And as the pronunciation they have for [can] is not feasible in our language, and it has such an aspiration that only an is understood, it came to be called Can, which was further corrupted, for the common people say Cão’]. 
(1) a. Tuymecão / Tuymican = Tuyme khan

b. Tibremvucão / Tybrem vucam = Tibremvu khan

c. Passilau Vacão = Passilau Va khan

\subsection{The term khaan as part of an opaque expression}

The cases above show a term (khaan) in a context where it is possible to identify not only the expression, but the meaning (at the end of the word and as part of a proper name). That the English version shows variation might possibly be related to the fact that the meaning is not intuitive. In addition, there is another example where the same meaning 'king' appears in a proper name, this time in an explicit way, since Pinto provides a literal translation.

Table 2. The term cau in the context of a complex phrase.

\begin{tabular}{|l|l|}
\hline 1614 & \multicolumn{1}{|c|}{1653} \\
\hline $\begin{array}{l}\text { No meyo desta tribuna estaua hũa grande estatua } \\
\text { de prata deitada em hum leyto do mesmo, que se } \\
\text { chamaua Abicau nilancor, que quer dizer, deos da } \\
\text { saude dos Reys, que tãbem se tomara no templo de } \\
\text { Angicamoy de que atraz fiz menção }\end{array}$ & $\begin{array}{l}\text { Statue of silver called Abicau Nilancor, which signi- } \\
\text { fies, the God of the health of Kings, that had been } \\
\text { also taken in the Temple of Angicamoy. }\end{array}$ \\
\hline
\end{tabular}

In the concordance of Table 2, the identification of the corresponding term is not as intuitive as in the previous examples of Table 1. Even if Pinto provides more information, as there is a direct translation following the original expression, 'God of the health of kings', the number of morphemes and syntactic relations involved is higher now. The difference with respect to the terms in Table 1 is obvious, for although they lacked a literal translation, their meaning was inferable from context as part of a simple phrase of the form PROPER NAME + KING (favoured by the fact that khaan, although exotic, was a word already known).

Accepting Pinto's translation as valid, the segment closest to Mongolian khaan in Abicau nilancor is cau. This implies that the same term has two different spellings in the text (cf. Pt. cão in Table 1 vs. cau in Table 2). This variation is in need of explanation.

\section{IN SEARCH OF ADDITIONAL CORRESPONDENCES}

There is another word in the text for which a clear semantic correspondence can be established. Pinto mentions Singrachirau as the word for the Great Wall (Table 3). ${ }^{8}$ The Mongol form of this toponym would not have been accessible to the editor or translator of the text in the $16^{\text {th }}$ century, but it is accessible to the modern reader. The contemporary terms are čagan kerem 'white forti-

${ }^{8}$ Given its stated denotation, Aubin (2010: 158. n. 18) contemplates to interpret this word as an 'echo' of Chinese chángchéng 長城 'long wall', but her particular wording already acknowledges the lack of proper sound correspondences. Charignon \& Ménard (1935: 280), in turn, go to great interpretative lengths to come up with a compound of sin k'eou 新 $\square$ (from sin pei k'eou 新北 $\square$ 'new northern passage') plus either si-lou 四路 'west road' or sié-lou 斜路 'cross road', thus interpreting the word as a (made-up) pars pro toto. 
fication' in most modern Central Mongolic varieties (Chakhar, Sönit, Kharchin, Qinghai Oirat [Sun 1990: 558], Khalkha, Khorchin) and sira kerem 'yellow fortification' in some Oirat varieties (Alasha, Xinjiang Oirat of Bayangol) and Eastern Yugur (Sun 1990: 558). ${ }^{9}$

While a certain similarity is intuitive, the rendering of the term in historical Portuguese is still so different that it would be nearly impossible to reconstruct the original Mongolic pronunciation from it. In order to explain this variation, we can proceed by assuming a cognate form and use the differences in writing to establish correspondences between different grapheme combinations and their underlying phonemes.

Table 3. Concordances of Singrachirau.

\begin{tabular}{|l|l|}
\hline \multicolumn{1}{|c|}{1614} & \multicolumn{1}{|c|}{1653} \\
\hline $\begin{array}{l}\text { Passando daquy para diante chegou aos muros de } \\
\text { Singrachirau, que saõ os de que atras disse que } \\
\text { diuidem estes dous imperios da China \& da Tar- } \\
\text { taria, \& não achando nelles resistencia algũa se } \\
\text { foy alojar da outra banda em Pamquinor, que era } \\
\text { a primeyra cidade sua, que estaua tres legoas deste } \\
\text { muro de Singrachirau, \& ao outro dia chegou a Xi- } \\
\text { pator onde despidio a mayor parte da gente. }\end{array}$ & $\begin{array}{l}\text { I have said heretofore, do divide those two Empires } \\
\text { of China and Tartaria; There meeting with no resi- } \\
\text { atance hent and lodged on the further side of it } \\
\text { and seated some three leagues from the said wall, } \\
\text { and the next day he marched to Psipator, where he } \\
\text { dismissed the most part of his people. }\end{array}$ \\
\hline
\end{tabular}

The Portuguese term Singrachirau can be split into its two parts, singra and chirau, and then be compared to its (potential) Mongolic cognates. Of these, the correspondence between Mongolic kerem and Portuguese chirau is relatively unproblematic, while Portuguese singra must be compared to both čagan 'white' and sira 'yellow'.

The term kerem 'fortress, wall' < 'encirclement' appears to be a Turkic loan (Doerfer 1975: 300-302) and is not attested in Middle Mongol proper except in some borrowed Kipchak place names in the Secret history of the Mongols $(\$ \$ 262,270,274)$ like kiwa menkermen 'Kiev'. In Ming glossaries, it is transcribed as kèrèn 克賃 [ kèlin (cf. Mathews 1943: page 468, entry 3107)] with the translation '墙壁 biānqiáng = border wall' (in the second Sino-Mongol glossary of 武備志 Wǔbèizhi 'Remarks on Military Preparations') (Apatóczky 2016: 11,113) and as 克勒目 kèlèmù with the translation '墻 qiáng = wall' (in 北虜譯語 Běilǔ yiyǔ) (Apatóczky 2009: 33, 117), enabling us to establish a form $k^{h}$ erem for the $16^{\text {th }}$ century. ${ }^{10}$ It is realized in modern Mongolic varieties as xərəm (Kharchin, Sönit, Chakhar), xirəm (Khalkha), $k^{h}$ irim (Qinghai Oirat) or $k^{h}$ erem (Alasha,

\footnotetext{
9 To represent these terms in a dialect-neutral way for citation purposes, they are displayed as if transcribed from Mongol script.

${ }^{10}$ Christopher Atwood (p.c., 9/8/2019) contemplates identifying a word from a passage in the Yuánsh (juăn 3, p. 49) as a place name containing the variant kermen: 冬, 帝駐踶阿塔哈帖乞兒蠻。'Winter. The emperor made his temporary residence at Ataghatai-Kermen'. In Yuan era Chinese transcription, the last seven characters would be read $a$-ta-Xa-te-kir $r-m A N$, where $\langle\mathrm{X}>$ represents $q / \mathrm{G},\langle\mathrm{A}>$ represents $a / e,\langle\mathrm{~N}\rangle$ represents $n / l / r$, and open syllables might require the reconstruction of omitted $-k / q / t / b$. Atwood suggests to read this as Ataghatai-Kermen 'envious wall', which might be a name for Ögedei's wall built to corral game that he lists as one of his bad deeds in the Secret history (\$281). He acknowledges that identifying -te with the comitative -tai and reinterpreting $i$ as $e$ in the syllable kir would reflect progressive sound changes that are only sparsely attested at this early stage. A second problem is that it requires the form kermen rather than kerem which Doerfer suggests is a later development from kerem that did not affect Mongolic.
} 
Xinjiang Oirat of Bayangol) $\sim k^{h}$ eram (Eastern Yugur), corresponding to Portuguese chirau. The Portuguese spelling $<\mathrm{ch}>$ could be indicative of a palato-alveolar affricate or of an aspirated sound (see 5.1 below). The first reading would suggest that the word was borrowed from a Mongolic variety in which the sound change Proto-Mongol ${ }^{\star} k^{h}>x$ (Svantesson et al. 2005: 198-200) had already taken place, while the second reading could correspond to either Mongolian sound. The palatal vowel $<\mathrm{i}>$ in Portuguese would most closely correspond to one of the varieties in which the sound change $e>i$ in word-initial syllables (Svantesson et al. 2005: 182) has taken place (Khalkha, Qinghai Oirat). A sound change with a similar result that would have involved a deaccented, reduced first-syllable ${ }^{\star} e(>>>)$ is reported for several Southern Mongolic languages (Nugteren 2011: 104) and possibly Ordos (Serengnorbu 1996; Möngkebuyan 1990, as cited in Svantesson et al.2005: 182), i.e. those varieties in which the accent shifted to the last syllable. Since the contrast between different nasal vowels in word-final position was being lost in the transition from Old to Modern Portuguese (Cardeira \& Fernandes 1999; Parkinson 2002) and even nowadays Portuguese $<\mathrm{em}>$ is realized with different degrees of vocalic openness depending on dialect (CLUP, 2012), ${ }^{11}$ the final syllable <au> would correspond to a sequence $\mathrm{Vm}$ irrespective of the specific vowel used in Mongolic (e/ə/i).

The term singra can be compared to Mongolic čagan as used in the more widespread form čagan kerem 'white fortification'. Čagan here corresponds to Proto-Mongolic ${ }^{\star} \mathrm{t}{ }^{\mathrm{h}} \mathrm{agaan}$ 'white' [Nugteren 2011:298] > Middle Mongol ${ }^{*}\left[\mathrm{t} \int^{\mathrm{h}}\right.$ agaan] $.{ }^{12} / \mathrm{t} \int^{\mathrm{h}} /$ was retained in Chakhar and Kharchin, but changed into $/ \mathrm{J} /$ in Khorchin (see e.g. Bayancogtu 2002) and $/ \mathrm{ts}^{\mathrm{h}} / \mathrm{in}$ Sönit, Qinghai Oirat (cf. Sun 1990: 558) and Khalkha. Since at least the middle of the 16th century Portuguese lacks an alveolar affricate /ts/ (Martings 2016: 4; Gementi-Spolzino 2018: 91-92), so <s> /s/ would have been the best possible match. The identity of the subsequent initial vowel is more problematic. All modern Central Mongolic varieties have [a] in this word. There are other Mongolic languages in which /i/ was regressively assimilated to the preceding palatal consonant (Nugteren 2011: 298), specifically Southern Mongolic varieties in which the first syllable got de-accentuated (e.g.,

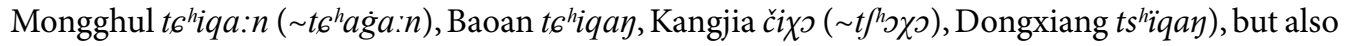
Dagur ( $\left.t f^{h} i \gamma a:(n)\right)$. However, these are languages that must have split away from the Central Mongolic mainstream in Middle Mongol times and would probably not have been an influential part of that mainstream in the $16^{\text {th }}$ century. Still, the variation with $/ \mathrm{i} /$ is even attested in (Late Western) Middle Mongol itself as tfhiya:n ( tfhaya:n) (Nugteren 2011:298), and consequently a source variety that had /i/ instead of /a/ in this position is marginally conceivable. The second consonant of $\check{c} a \mathrm{Gan},{ }^{*} \mathrm{~g}$, may correspond to $[\mathrm{g}],[\mathrm{G}]$ and $[\mathrm{G}]$ in inter-vocalic position in Khalkha (Svantesson et al.2005: 12), a range of realizations that, phonetically, can be found in several modern Mongolian varieties. This is not a particularly good match for Portuguese $<$ ng $>$ or $<$ ngr $>$, though it would of course match $<$ g $>$ quite well.

On the other hand, the term singra can also be compared to Proto-Mongolic * sira $>$ Middle Mongol fira 'yellow' (Nugteren 2011: 492, though $\dddot{i}$ is retained in some modern varieties) as used

\footnotetext{
${ }^{11}$ See http://cl.up.pt/arquivo/mapas/mapas.html for an inventory of phonemes and its contemporary dialectal distribution.

12 The transcription cagagan which more accurately allows to predict the length of the second vowel is attested only once in Middle Mongol, while the predominant spelling was caGan (cf. e.g. Tumurtogoo \& Cecegdari 2006: 347-348), which also became entrenched in orthography later on. While some scholars including Tumurtogoo opt for a transcription such as čaya: $n$ that indicates the length of the second vowel, we prefer to not teleologically superimpose features that have no orthographic correspondence.
} 
in the less widespread term sira kerem. The three contemporary varieties in which this term is used realize the first word as / Jara/ (Alasha), / far/ (Xinjiang Oirat of Bayangol) (Sun 1990: 558) or as / Jar/ (Sun 1990: 558) / $\mathrm{ra} /$ (Nugteren 2011: 492) (Eastern Yugur). The Great Wall was built from yellow-colored clay in the Alasha/Gansu area and would therefore be called accordingly in these parts (Gandigcoo p.c. 20/8/2019). Here, Portuguese <s > would match Mongolic [J] /s $\sim$ /. The comparison with other non-Mongolic place names cited in Peregrinação (Pinto 1614), especially the case of Narsinga (modern Narashima), opens the hypothesis that $<$ si $>$ was specifically employed by Pinto to represent a palatal fricative $/ \mathrm{J} / .<\mathrm{i}>$ would directly represent $/ \mathrm{i} \sim \mathrm{i} /$, and it is quite plausible that $\mathrm{i}$-breaking had not yet taken place in the $16^{\text {th }}$ century predecessors of the modern Mongolic varieties that now show /a/ instead. ${ }^{13}<$ ra $>$ would be a perfect match as well, since the loss of finite short vowels in Alasha is most likely a relatively recent development (and in the neighboring Ordos dialect never took place at all). Finally, while reflexes of ${ }^{\star}$ sïra do not contain a nasal segment in any known variety of Mongolic, it is also conceivable that $<$ ng $>$ in the Portuguese transcription merely indicates the nasality of the preceding vowel. While attributing this quality to a Mongolic $* i>i$ is not warranted, this would yield a set of corresponding segments. Consequently, it is more plausible that singra reflects a Mongolic source fira 'yellow'.

\section{PHONETIC VALUE OF THE PORTUGUESE TRANSCRIPTIONS}

\subsection{The velar fricative}

Pinto uses $\langle\mathrm{c}>($ cão, cau $\sim$ khaan $)$ and $<\mathrm{ch}>($ chirau $\sim$ kerem $)$ for what in the source language would have been an aspirated plosive (Middle Mongol) or fricative (most modern Mongolian varieties) with velar and uvular variants. Portuguese lacks a velar fricative, so its velar stop / $\mathrm{k} /$ would in both cases have been the most similar sound in the target language. However, the grapheme $\langle\mathrm{c}\rangle$ in Portuguese only has a velar value before $\langle\mathrm{a}\rangle,\langle\mathrm{o}\rangle$ and $\langle\mathrm{u}\rangle$, while $\langle\mathrm{c}\rangle$ followed by $<\mathrm{i}\rangle$ or $\langle\mathrm{e}\rangle$ is most commonly read as a sibilant /s/ which already holds true at the time of Peregrinação. For this type of environment, Pinto opted to use $<\mathrm{ch}>$. This digraph had several phonetic realizations, e.g. as a palato-alveolar affricate $/ \mathrm{t} f /$ which was preserved in northern dialects or as a palato-alveolar fricative $/ \mathrm{J} /$ which finally prevailed through the Lisbon standard, ${ }^{14}$ but in borrowings from classical languages it was pronounced as an aspirated sound different to any other Portuguese phoneme. For instance, the grammarian Duarte Nunes de Leão (1576: fol. 5r) describes $<\mathrm{ch}>$ as the spelling to represent the aspiration of Greek and Latin names as in Achilles

13 For instance, the Mongolian-Chinese glossary in the $17^{\text {th }}$ century source Ming Lulongsai lüe (which is, however, based on similar glossaries that go back to the late $14^{\text {th }}$ century by which it might be influenced) still transcribes 'yellow' as shīlá 失剌 (Apatóczky 2016: e.g. 9, 48).

${ }_{14}$ The neutralization of the voiceless palato-alveolar affricate into a voiceless palato-alveolar fricative is considered to become first attested (though still not accepted in the norm) towards the second half of the $17^{\text {th }}$ century, that is, well after the time of Pinto's writing and the publication of Peregrinação. For a review of the literature on the historical evolution of the palatal fricatives and affricates (the more generic term 'palatal' instead of 'palatoalveolar' is more often used in Portuguese linguistics) see Gementi-Spolzino (2018: 82-101). Considerations on the dialectal distribution and chronological development of the affricate / $\mathrm{t} / \mathrm{can}$ be found in A. Pinto (1981), Pérez (2014: 41-42) and Martins (2016: 6). 
and patriarcha. Similarly, the historian Diogo de Couto (1612: fol. 212r) states that the original reading of cão is aspirated (see note 7 above).

Overall, the solution adopted by Pinto for a sound that did not exist in Portuguese appears quite coherent:

1) It employs the same grapheme $<\mathrm{c}>$ to represent Mongolic $/ \mathrm{k}^{\mathrm{h}} /$ or $/ \mathrm{x} /$, either as part of a digraph or as a single character.

2) The grapheme $\langle\mathrm{c}\rangle$ before the vowels $\langle\mathrm{a}\rangle,\langle\mathrm{O}\rangle,\langle\mathrm{u}\rangle$ was unambiguously pronounced as a velar stop in Portuguese, a sound that, even though unaspirated, was perceived as close enough to represent the Mongolic source. Hence Pinto only used the digraph $<\mathrm{ch}>$ in those cases where the pronunciation of $\langle\mathrm{c}\rangle$ would be completely different for Portuguese readers.

3) The use of $\langle\mathrm{ch}>$ for an aspirated (most likely velar) sound was prescribed as valid in Portuguese grammars roughly contemporary to Pinto. Furthermore, while expressions from classical languages would be perceived as exotic in Portuguese, this would also be the case for the Mongolian names transcribed by Pinto.

\subsection{The nasal consonant in final position}

In Portuguese, the use of digraphs consisting of a vowel and a nasal consonant such as <an $>$ or $<\mathrm{em}>$ to represent a nasal vowel is common in word-internal position (e.g. tanto /'tẽtu/, tempo /'tẽpu/), while the representation of nasal vowels in word-final position is slightly more difficult

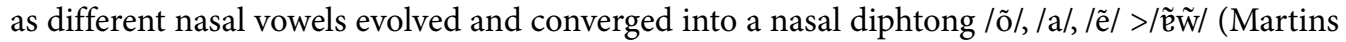
2016: 12) written as -ão or -am (see 3.1 above). Theoretically, the same acoustic reality can be interpreted either as a single phoneme (a nasal vowel, e.g. $/ \tilde{\mathfrak{e}} /$ ) or a diphonemic realization of a slightly nasalized oral vowel followed by a velar nasal consonant (e.g. /an/) (Rothe-Neves \& Reis 2012; Veloso 2019). That is, a sequence that for Mongolic is usually attributed the phonological status of a vowel plus a nasal consonant (/ay/) corresponds to a sequence that in the Portuguese phonological tradition is simply interpreted as a nasal vowel $(/ \tilde{\mathrm{e}} /)$.

Table 4. Relationships between meaning and transcriptions of terms involving a vowel plus nasal consonant in Mongolic

\begin{tabular}{|l|l|l|l|}
\hline Meaning type & Portuguese (1614) & English (1653) & Context \\
\hline $\begin{array}{l}\text { NON-TRANSPARENT } \\
\text { TERMS }\end{array}$ & Singrachirau & Singrachirau & $\begin{array}{l}\text { The context does not allow } \\
\text { the identification of morphemes } \\
\text { even if a translation is provided. }\end{array}$ \\
\hline $\begin{array}{l}\text { TRANSPARENT } \\
\text { TERMS }\end{array}$ & Tuymicaun nilancor & $\begin{array}{l}\text { Tuymicoa } \\
\text { Tuymican } \\
\text { Tybrem vucam }\end{array}$ & $\begin{array}{l}\text { The context allows the identifi- } \\
\text { cation of morphemes (anthropo- } \\
\text { nym referring to a king plus the } \\
\text { term khaan that is already in use } \\
\text { as a common name) }\end{array}$ \\
\hline
\end{tabular}

Table 4 shows the Portuguese and English correspondences for terms with endings in vowel + velar nasal consonant (khaan) and bilabial nasal consonant (kerem) transcribed as -ão or -au in 
Portuguese. When the term is known (khaan) and appears in a context that facilitates its identification, it is spelled as -ão in Portuguese and -am or -an in English (while Tuymicoa in the English text, which is later written as Tuymican, is probably a typographical error). However, if the term is completely unknown or if there are elements that make its identification difficult, we find the ending -au (Abicau nilancor and Singrachirau).

A hypothesis that explains this variation is to assume that the original manuscript used a different spelling ${ }^{15}$ which was later reinterpreted in the editorial process as - $\tilde{a} o$. For those forms where the meaning is inferable from the context (interpreted as a morpheme in word-final position to refer to a king), the editor would have no problems to standardize the spelling from $<$ au $>$ to $<$ ão $>$. However, for opaque expressions, there would be no elements of analogy that could allow the editor to identify <au> as representing a nasal value, so the manuscript's original script is kept, as this is also a valid diphthong in Portuguese (though with an oral, non-nasal pronunciation, hence the difficulties to relate it to the Mongolic terms at its face value).

\section{VOCABULARY RETRIEVED FROM TARTAR PLACE NAMES}

Toponyms are a good starting point to apply the rules we have identified so far to explain the phonetic values of graphemes which have a different reading in standard Portuguese nowadays. Hence, from the study of place names only, it is possible to extract a small vocabulary that defines probable or secure sound correspondences with Mongolic. Table 5 shows lexical units as written in Peregrinação along with their equivalent Mongolic forms and meaning. The nominal phrase column shows the term as part of the place name in a position consistent with appositions (Janhunen, 2012a: 190-191) or the typical nominal phrase structure of Mongolian where the modifier precedes the nucleus, so apart from phonetics and semantics, there is syntactic correspondence.

Table 5. Vocabulary extracted by comparing pairs of semantic correspondence after applying rules of phonetic equivalence

\begin{tabular}{|l|l|l|l|}
\hline Peregrinação (1614) & Mongol script & Meaning & Phrase \\
\hline cão & qaGan & king & Tuymecão \\
\hline tuyme & tümed & tümed (demonym) & Tuymecão (the tümed khan) \\
\hline $\begin{array}{l}\text { Singrachirau } \\
\text { Chirau } \\
\text { Singra }\end{array}$ & $\begin{array}{l}\text { sira kerem } \\
\text { kerem } \\
\text { sira? } \\
\text { čagan? }\end{array}$ & $\begin{array}{l}\text { Great wall } \\
\text { wall } \\
\text { yellow } \\
\text { white }\end{array}$ & Singrachirau \\
\hline $\begin{array}{l}\text { Singua } \\
\text { Singa }\end{array}$ & čagan? & white & $\begin{array}{l}\text { Singuafatur } \\
\text { Singapamor }\end{array}$ \\
\hline $\begin{array}{l}\text { bator } \\
\text { fatur }\end{array}$ & ba'atur & hero & $\begin{array}{l}\text { Xibator (Psibator, 1653) } \\
\text { Singuafatur }\end{array}$ \\
\hline (pa)mor & mörön, naGur? & river, lake & Singuapamor \\
\hline
\end{tabular}

15 For instance, both < au > or even < an > would be dialectally and historically plausible original spellings that an editor could have changed into representations more in line with his personal speech and writing conventions. Alternatively, the editor might simply have misread $<\mathrm{n}>$ as $<\mathrm{u}\rangle$. 
The analyses below have illustrative purposes only. They are intended to serve as a starting point for a more in-depth study that would proceed from deciphering place names to other terms or whole sentences that Pinto transcribed in his report.

The form Tuymicão (Tuymican) appears as a place name, but the context 'the city of Tuymicão' allows for an interpretation where the referent is a person, as in 'the city of the khan Tuymi'. Considering phonetic similarity and the historical context of the events described here (the siege of the city of Beijing in the mid- $16^{\text {th }}$ century through Altan Khan of the Tümed), it would be plausible if the first term, Tuymi, refers to the tümed people. This endonym itself is a plural form of tüme (n) 'ten thousand; military unit of ten thousand soldiers', which in modern realizations mostly differs with regard to its first vowel (normally $[\mathrm{u}] \sim[\mathrm{u}]$, Sönit: $[\Theta]$, Oirat: $[y]$, Eastern Yugur: [e]) and the widely variable obligatoriness of unstable $n$ (see Sun 1990). The absence of word-final $d[\mathrm{t}]$ in tuymi could thus either be accounted for by assimilation to $/ \mathrm{k}^{\mathrm{h}} /$ in the subsequent word or by the use of the variant tüme( $n$ ) with unstable $n$ in the first place. However, since the exact meaning is neither translated nor directly inferable from the context, this reconstruction should be received with caution.

There are two additional toponyms, Singuafatur and Xipator (Psipator in the English version), that appear to be compounds of an attributive modifier and a modified noun. It is possible that singua can be compared to singra, especially if it is to be read as čagan 'white' rather than sira 'yellow'. In the first two place names, the second part fatur pator can be compared to Proto-Mongolic *baatur 'hero', which in most modern varieties is pronounced with an initial unvoiced unaspirated stop /p/ (Janhunen 2012a: 28; Svantesson et al. 2005: 17-18). $<\mathrm{f}\rangle$ in fatur must have been an inaccurate rendering of $/ \mathrm{p} /$ since neither ${ }^{\star} / \mathrm{f} /$ nor ${ }^{*}[\mathrm{f}]$ would have been present in $16^{\text {th }}$ century Mongol. The use of baatar in person-derived or anthropocentric place names such as Ulaanbaatar 'red hero' is at least attested in modern times. The term would have been recorded before the sound change $\mathrm{u}[\mathrm{v}]>\mathrm{a}[\mathrm{a}]$ removed short close back rounded vowels from non-initial syllables of all Central Mongolic varieties.

Table 6. Concordances of Singapamor

\begin{tabular}{|c|c|}
\hline 1614 & 1653 \\
\hline $\begin{array}{l}\text { E correndo por este esteyro a Leste, \& a Lesnordes- } \\
\text { te, \& em partes a Lessueste conforme âs quedas por } \\
\text { onde a agoa fazia sua euasaõ, chegamos ao lago de } \\
\text { Singapamor, que os naturais da terra nomeão por } \\
\text { Cunebetee, que, segundo a enformação que nos } \\
\text { derão, tinha em roda trinta \& seys legoas, no qual } \\
\text { vimos tanta diuersidade de aues de toda a sorte, que } \\
\text { me não atreuo a podelo dizer. }\end{array}$ & $\begin{array}{l}\text { Through this straight running East, as also East, } \\
\text { North-east; and sometimes East, and by East, accor- } \\
\text { ding to the windings of the water we arrived at the } \\
\text { Lake of Singapamor, called by them of the Country } \\
\text { Cunebetea, which was, as our Pilots affirmed, six } \\
\text { and thirty leagues in extent, where we saw so many } \\
\text { several sorts of birds, that I am not able to recount } \\
\text { them. }\end{array}$ \\
\hline $\begin{array}{l}\text { Deste lago de Singapamor, que a natureza por } \\
\text { obra admirauel abrio no coração desta terra, saem } \\
\text { quatro rios muyto largos \& fundos, hũ por nome } \\
\text { Ventrau, que corta direyto a Oeste toda a terra do } \\
\text { Sornau de Sião, \& faz sua entrada no mar pela barra } \\
\text { de Chiãtabuu, em vinte \& seis graos. }\end{array}$ & $\begin{array}{l}\text { Out of this Lake of Singapamor (which as an ad- } \\
\text { mirable Master-piece nature hath opened in the } \\
\text { heart of this Country) do four very Iarge and deep } \\
\text { rivers proceed, whereof the first is named Ventrau, } \\
\text { that runneth Eastward through all the Kingdoms } \\
\text { of Sornau and Siam, entring into the Sea by the Bar } \\
\text { of Chiamtabuu, in six and twenty degrees; }\end{array}$ \\
\hline
\end{tabular}


The last toponym to be discussed here, Singapamor, is introduced by Pinto in the passages shown in Table 6 as a lake already outside of the Tartar domains. ${ }^{16}$ This hydronym also seems to have a modifier preceding the central term. For the nucleus, there are two conceivable Mongolic readings, namely, Proto-Mongolic *mören/müren 'river' (Nugteren 2011: 448) and *naur 'lake' > Central Mongolic /nuur/, mostly [nv:r] (cf. Nugteren 2011: 453). For equating <mor> with mören, -en would have to be understood as unstable $-n$, but variants without - $n$ are only found in Dagur and Buryat, both very unlikely donors due to their geographic location in north-eastern Greater Mongolia. Reanalyzing mören as mör-en with an unstable $n$ is a mistake that an intermediate learner could plausibly have made, though. Alternatively, if the term goes back to *naur 'lake' (as suggested by Nugteren, p.c., 19/2/2019), Pinto would have confused $<$ m $>$ with $/$ n/, while $<$ o $>$ as [ひ] (a phoneme missing in Portuguese) is still relatively plausible. ${ }^{17}$ Semantically, this second interpretation more closely resembles the desciption in the text. However, if the initial element singua $\sim$ singa $\sim$ singra would be identified as variant spellings of 'white', this would leave $<$ pa $>$ as an unexplained element which is problematic for both interpretations discussed here since this short element is unlikely to represent a full morpheme.

\section{CONCLUSION}

The terms discussed above provide a solution for what is the biggest problem to start deciphering the Mongol place names transcribed by Pinto: to explain the phonetic values of graphemes used to represent phonemes either inexistent in Portuguese or not completely standardized at the time of Pinto's writing. This is the case of $<\mathrm{ch}>$ which has an affricate palatal value in $16^{\text {th }}$ century Portuguese but in Pinto's writing represents a Mongolic velar plosive or fricative. The other examples considered are the diphthongs <ão $>$ and $<$ au $>$ which correspond to a vowel plus nasal consonant in Mongolic, a sequence that, even if it could have a phonetic realization similar to Mongol in Pinto's times, has converged in a nasal diphthong in modern standard Portuguese.

Pinto wrote his work in the middle of the $16^{\text {th }}$ century as the result of accumulating a vital experience in the first half of the century in Asia. However, what has been transmitted to us is a posthumous book published in the following century, in which editors would have modernized and standardized the manuscript according to the orthographic uses of the moment. This contrast between the author's original writing and later standardization is a possible explanation for the different solutions found in Pinto's transcript for Mongolic word-final nasal consonants.

\footnotetext{
16 This lake is mentioned in the chapters referring to the Tartars because Pinto is travelling with a Tartar diplomat that aims to bring the Portuguese safe to the sea. However, Pinto also makes it clear that the form Singapamor is an exotoponym for Cunebetee (see table 6, concordance 1). The form Singuapamor (which seems a variant of Singapamor) is also mentioned as an exotoponym of the lake Chiammay in a different passage of the Peregrinação (Pinto 1614: chapter 182). The place name Chiammay is more often used by Pinto to refer to a kingdom identified with Chiang Mai in northern Thailand. See Flores \& Breazeale (2010: 237. n. 3, 240. n. 4) and Grawosky (2010: 208-209. n. 9) for the geographical and historical context in Pinto. An alternative explanation of this toponym and its possible location is proposed by Charignon \& Ménard (1935: 311-343).

17 This would require the donor dialect to be more progressive than its representation in Mongolian-Chinese glossaries like the $17^{\text {th }}$ century Ming Lulongsai lüe, which preserves the original diphthong /av/ as in nàwúe r 納匹 兒 'lake' (Apatóczky 2016: 8, 125). However, as mentioned earlier, it is conceivable that this glossary, based on much older materials, errs on the conservative side.
} 
The expressions studied after solving the phonological value of these graphemes allowed for an interpretation of the place names in Pinto's writing that is coherent not only with the semantics of the terms first identified on grounds of phonetic similarity. It was hence possible to identify new lexical units and propose solutions for the reading of further place names that also agree with the characteristics of well-known Mongol toponyms.

\section{REFERENCES}

\section{Primary sources}

BARros, João 1540. Grammatica da lingua portuguesa. Lisboa: Lodouicum Rotorigiu. http://purl.pt/12148.

BArros, João 1615. Quarta decada da Asia. Madrid: Impressão Real.. http://objdigital.bn.br/objdigital2/ acervo_digital/div_obrasraras/or1467091/or1467091.pdf

Couto, Diogo 1612. Decada quinta da Asia. Lisboa: Pedro Casbeeck. http://purl.pt/29502

LEÃo, Duarte Nunes 1576. Orthographia da lingoa portuguesa. Lisboa: Ioão de Barreira. http://purl.pt/15

Mello, Fernando Ribeiro (ed.) 1989. Peregrinação \& Cartas. Lisboa: Afrodite.

Oliveira, Fernando 1536. Grammatica da lingoagem portuguesa. Lisboa: Germão Galharde. http://purl. $\mathrm{pt} / 120$

Pinto, Fernam Mendez 1614. Peregrinaçam. Lisboa: Pedro Crasbeek. http://purl.pt/82

Pinto, Fernão Mendes 1653. The voyages and adventures, of Fernand Mendez Pinto, a Portugal ... done into english by H. C. Gent. London: printed by J. Macock, for Henry Cripps, and Lodowick Lloyd. http:// purl.pt/16425

Polo, Marco 1502. Ho liuro de Nycolao Veneto. Ho trallado da carta de huu[m] genoues das ditas terras... Lyxboa: Valentym Fernãdez. http://purl.pt/14703

Purchas, Samuel 1625. Hakluytus posthumus or Purchas his Pilgrimes. London: William Stans for Henrie Fetherstone. http://purl.pt/23391

\section{Secondary literature}

Alves, Jorge Santos (ed.) 2010. Fernão Mendes Pinto and the Peregrinação (4 vols.: Studies, restored Portuguese text, notes and indexes). Lisbon: Fundação Oriente.

Apatóczky, Ákos Bertalan. 2009. Yiyu - An Indexed Critical Edition of a Sixteenth Century Sino-Mongolian Glossary. Folkestone: Global Oriental.

ApatóczKy, Ákos Bertalan 2016. The “Translation”(譯部) Chapter of the Late Ming Lulongsai lüe (盧龍塞 略). Leiden: Brill.

Aubin, Françoise 2010. ' [Notes on chapters 121-128.]' In: Alves 2010: vol. 3, 150-164.

BALK, Michael and Juha JanHUNEN 1999. 'A new approach to the romanization of Written Mongol'. Studia Orientalia Electronica 87: 17-28.

Barreto, Luís Filipe 2010. ‘Fernão Mendes Pinto and the Jesuit Connection.' In: Alves 2010: vol. 1, 55-87.

BAYANČogtu 2002. Qorčin aman ayalgun-u sudulul [A study of the Khorchin dialect]. Kökeqota: Öbür mongGul-un yeke surGaGuli-yin keblel-ün qoriy-a.

Brosig, Benjamin and Elena Skribnik 2018. 'Evidentiality in Mongolic.' In: Alexandra Aikhenvald (ed.) Oxford Handbook of Evidentiality. Oxford: Oxford University Press, 554-579. 
Canosa, Afonso Xavier 2013. 'Notas biográficas e estudo das referências documentais de Fernão Mendes Pinto [Biographic notes and study of documental references to Fernão Mendes Pinto].' Veredas [Revista da Associação Internacional de Lusitanistas] 20: 9-34.

Canosa, Afonso Xavier 2018. 'Comparison of segmentable units as indicators of two texts being parallel'. In: Pedro Rangel Henriques, José Paulo Leal, António Menezes Leitão and Xavier Gómez Guinovart (eds.) 7th Symposium on Languages, Applications and Technologies (SLATE 2018) [OASICS 62]. Dagstuhl: Leibniz-Zentrum für Informatik, 16:1-16:7. http://drops.dagstuhl.de/opus/volltexte/2018/9274/

Cardeira, Esperança and Maria Alice Fernandes 1999. 'As terminações nasais nas actas das vereações de Loulé (séc. XIV-XV) [The nasal endings in the Municipal Decrees of Loule ( $14^{\text {th }}$ to $15^{\text {th }}$ centruries)].' In: Actas do XIV Encontro Nacional da Associação Portuguesa de Linguística. Vol. I, 251-263.

Clup 2012. Arquivo Dialetal do CLUP [Dialectal Archive of the Linguistics Center of the University of Porto]. Centro de Linguística da Universidade do Porto. (Online access: http://cl.up.pt/arquivo).

Charignon, A. J. H. and M. Ménard 1935. A propos des voyages aventureux de Fernand Mendez Pinto. Pékin: Imprimerie des Lazaristes.

Collis, Maurice 1949. The Grand Peregrination. London: Faber and Faber.

Doerfer, Gerhard. 1975. Türkische und mongolische Elemente im Neupersischen. Volume IV. Wiesbaden: Franz Steiner.

Flores, Maria da Conceição and Kennon Breazeale 2010. '[Notes on chapters 181-189].' In: Alves 2010: vol. 3, 237-248.

Gementi-SPolzino, Mariana Moretto 2018. Consoantes fricativas: um estudo das relações entre letras e sons na lírica medieval galego-portuguesa [Fricative consonants: a study of the relations between letters and sound in Galegan-Portuguese medieval lyric poetry]. São Paulo: UNESP. Doctoral dissertation.

Grabowsky, Volker 2010. '[Notes on chapters 158-167]'. In: Alves 2010: vol. 3, 206-223.

Janhunen, Juha. 2003a. 'Preface and acknowledgements.' In: Juha Janhunen (ed.) The Mongolic languages. London: Routledge, xvi-xxiii.

Janhunen, Juha. 2003b. 'Proto-Mongolic.' In: Juha Janhunen (ed.) The Mongolic languages. London: Routledge, $1-29$.

Janhunen, Juha. 2012a. Mongolian. Amsterdam: John Benjamins.

Janhunen, Juha. 2012b. 'Romanizing Mongolian for the next century.' In: Ágnes Birtalan (ed.) Mongolian Studies in Europe 2: Proceedings of the conference held on the occasion of the 100th anniversary of the Mongolian revolution for independence, Budapest, 20 April, 2011. Budapest: Eötvös Loránd University, 153-167.

JiN, Guoping 2010a. '[Notes on chapters 55-87]' In: Alves 2010: vol. 3, 97-113.

JIN, Guoping 2010b. 'Some reflections on Mendes Pinto's knowledge of the Chinese language and the conceivable chinese bibliography of the Peregrinação'. In: Alves 2010: vol. 1, 319-330.

LipsKi, John 1973. 'On the evolution of Portuguese -ão.' Vox Romanica 32/1: 95-107.

Lopes, Marsília dos Santos 2010. 'Peregrinação by Fernão Mendes Pinto: A source of knowledge.' In: Alves 2010: vol. I, 257-270.

Martins, Ana Maria 2016. 'Introdução: O português numa perspetiva diacrónica e comparativa [Introduction: Portuguese in a diachronic and comparative perspective.' In: Ana Maria Martins and Ernestina CArrilho (eds.) Manual de Linguística Portuguesa [Handbook of Portuguese Linguistics]. Berlin/Boston: De Gruyter, 1-39.

Mathews, Robert 1972 [1931]. Chinese-English dictionary. [Revised American edition.] Cambridge, Mass.: Harvard University Press. 
MöngKebuYan 1990. 'Ordos aman ayalgun-u abiyalaburi-yin sistem [The phoneme system of the Ordos dialect].' MongGol kele bičig 1990/3: 25-36. [Non vidi.]

Nugteren, Hans 2011. Mongolic Phonology and the Qinghai-Gansu Languages. Utrecht: LOT. (Doctoral dissertation)

Parkinson, Stephen 2002. 'The Portuguese final nasals: documenting a chronology' Santa Barbara Portuguese Studies 6: 287-306.

PÉrez, Xosé Afonso Álvarez 2014. 'European Portuguese dialectal features: a comparison with Cintra’s proposal'. Journal of Portuguese Linguistics 13/1: 29-62.

PInto, Adelina Angélica 1981.'A africada č em Português [The affricate č in Portuguese].' Boletim de filologia 26: 139-192.

Poppe, Nicholas. 1954. Grammar of Written Mongolian. Wiesbaden: Harrassowitz.

Rothe-Neves, Rui and Camila Reis 2012. 'Uma bibliografia da nasalidade vocálica no português [A bibliography of the nasal vowels in Portuguese].' Letras de Hoje 47: 299-305.

Rybatzki, Volker 2003. 'Middle Mongol.' In: Juha Janhunen (ed.) The Mongolic Languages. London: Routledge, 47-82.

Rybatzki, Volker 2006. Die Personennamen und Titel der mittelmongolischen Dokumente: Eine lexikalische Untersuchung. Helsinki: Yliopistopaino Oy.

SERENGNorbu 1996. 'Ordos aman ayalgun-u e, i-yin soligdal-un tuqai [On the merger of e and $\mathrm{i}$ in the Ordos dialect].' MongGol kele bičig 1996/12: 38-40. [Non vidi.]

Sūn Zhú 孙竹 (ed.) 1990. Měnggŭ yŭzú yŭyán cídiăn 蒙古语族语言词典 [Dictionary of the languages of the Mongolic language family]. Xining: Qinghai renmin chubanshe.

Svantesson, Jan-Olof, Anna Tsendina, Anastasia Karlsson and Vivan Franzén 2005. The Phonology of Mongolian. New York: Oxford University Press.

Tumurtogoo, D. and G. Cecegdari 2006. Mongolian monuments in Uighur-Mongolian script (XIII-XIV centuries). Taipei: Academia Sinica.

Veloso, João 2019. 'Complex segments in Portuguese: The unbearable heaviness of being palatal'. In: Epelde Zendoia, Irantzu and Oroitz Jauregi Nazabal (eds.) Bihotz ahots. M. L. Oñederra irakaslearen omenez. Bilbao: Euskal Herriko Unibertsitatea, 513-526.

Open Access. This is an open-access article distributed under the terms of the Creative Commons Attribution-NonCommercial 4.0 International License (https://creativecommons.org/licenses/by-nc/4.0/), which permits unrestricted use, distribution, and reproduction in any medium for non-commercial purposes, provided the original author and source are credited, a link to the CC License is provided, and changes - if any are indicated. 